\title{
Operating Segments (IFRS 8)-Required Disclosure and the Specific-Characteristics of Kuwaiti Listed Companies
}

\author{
Faisal S. Alanezi ${ }^{1}$, Mishari M. Alfraih ${ }^{1} \&$ Saad S. Alshammari ${ }^{1}$ \\ ${ }^{1}$ Acounting Department at College of Business Studies, the Public Authority for Applied Education \& Training, \\ Kuwait \\ Correspondence: Faisal S. Alanezi, Acounting Department at College of Business Studies, the Public Authority \\ for Applied Education \& Training, Kuwait. Tel: 965-9005-5239. E-mail: fs.alanezi@ paaet.edu.kw
}

Received: November 5, 2015

Accepted: December 7, $2015 \quad$ Online Published: December 25, 2015

doi: 10.5539/ibr.v9n1p136

URL: http://dx.doi.org/10.5539/ibr.v9n1p136

\begin{abstract}
The aim of this article is to assess and examine the operating segment required-disclosure of companies listed on the Kuwait Stock Exchange (KSE) and the influence of certain variables that determine their extent of operating segment disclosures. Similar to the previous studies, the degree of operating segment disclosure is tested based on a disclosure index of the compulsory items of the International Financial Reporting Standard (IFRS) 8 (Operating segment). A regression model is estimated using Ordinary Least Squares analysis for a sample of 150 Kuwaiti companies listed on the KSE at the end of 2013 to examine the relationship between the degree of operating segment disclosure and the specific characteristics of Kuwaiti listed companies. The results reveal that the average level of operating segment disclosure was $54 \%$, ranging from $3 \%$ to $95 \%$. The results revealed that Kuwaiti listed companies with a higher level of compliance with the IFRS 8-required disclosures (Operating segment) were expected to be larger, highly growth and audited by audit firm associated with a Big-4 audit firm. In contrast with the more compliant, Kuwaiti listed companies with a lesser level of compliance with the IFRS 8-required operating segment disclosure were likely to be profitable. In contrast, company age, ownership diffusion, leverage and type of industry, were found to be not influencing the compliance with the IFRS 8-required operating segment disclosure. The findings deliver valuable insights and assistance to the regulatory and enforcement official bodies and to the investors in Kuwait on evaluating the existing operating segment disclosure practice among KSE-listed companies. Since the average level of operating segment disclosure was $54 \%$, this result recommends reviewing the monitoring system of the enforcement of required operating segment disclosure. Additionally, the results provide feedback about the drivers of operating segment disclosures practice.
\end{abstract}

Keywords: operating segments, IFRS 8, mandatory disclosure, Kuwait

\section{Introduction}

In 1990, Kuwait had adopted the international financial reporting standards (IFRSs) to overcome not having a clear mechanism to establish new domestic accounting standards (Alanezi, 2006). In addition, the purpose of the mandatory adoption of IFRSs was to enhance the confidence of the Kuwaiti business environment, send a signal that Kuwait was joining the international markets drive for accounting harmonization, and inform potential investors about the exist opportunities for international investment.

Disclosing material information related to companies is vital to the growth and improvement of capital markets (Saudagaran, 2004). Such kind of information helps stakeholders to estimate the value of a company and as a consequence improves the quality of financial decisions. Additionally, it helps investors and creditors in monitoring their investments.

Kuwait is such a developing country with an economy comprehensively depending on oil production and exportation as which is the main source of its income, the Kuwaiti stock market affords new opportunities for financing and investment in new businesses with a goal to diversify the sources of income alongside the oil production and exportation. In order to diversify its economy and to attempt to be quarantined from the economic effect of instable oil prices, the Kuwait government has allowed foreign investments in the securities traded in KSE. Indeed, foreign investment is needed to the Kuwait's economy to prompt growth in its capital market and to advance its economy as a whole. A study conducted by Epstein and Palepu (1999) stated that segment performance information is considered the main data for the purpose of investment decisions. 
A consolidated financial statement affords information about a company's general profitability, risk, and degree of company's growth. On the other hand, in order to make informed investment decisions, with the increasing diversification and complexity of business enterprises, investors and analysts have sought more value-relevant information (Alfraih \& Alanezi, 2011). To understand how the various components of a diversified firm behave economically, Investors and investment analysts need desegregation information. It is difficult, for investors and analysts to predict the overall amounts, timing, and risks of a complete company's future cash flows without such information, therefore investment analysts depend on segmental data to assess the investments (AIMR, 1993). Berger and Hann (2005) study show that disaggregated information is very useful to users of financial statements.

The International Accounting Standards Board (IASB) established the International Financial Reporting Standard (IFRS) 8 (Operating Segments) to help investors make economic decisions, The objective of IFRS 8 (operating segments) is to discrete financial information available, and whose results are reviewed regularly by the entity's Chief Operating Decision Maker (CODM) to assess the performance of a firm and resources allocation (IASB, 2013).

Previous studies have pointed out numerous problems on reporting of segment information disclosure in managerial discretion (Street \& Bryant, 2000). Prather-Kinsey and Meek (2004) state that companies to some levels, disclose segment-reporting, but not on a systematic manner, which could affect the level of compliance. Birt, Kend, and Xian (2007) claim that many corporate failures in Australia, the United States, and in other countries highlighted the vital role of disclosure. However, stakeholders concerned about compliance and non-compliance with segment-reporting disclosures. While many studies investigated segment-reporting matter in western countries, little consideration has been given to developing countries where the quality of accounting standards and their enforcement mechanisms are questionable. Because of scarcity of studies on operating segment-required disclosures in Kuwait, the drive of this paper is to assess both the operating segment required-disclosure practice according to IFRS 8 of companies listed on the Kuwait Stock Exchange (KSE) and the aspects that determine their level of operating segment required-disclosures. The findings of this study provide beneficial accounting information for analysts and external users because operating segments reports will provide them a better understanding of the overall companies' performance and, may assist them in their investment decisions.

Based on a comprehensive review of the segment disclosure literature, eight hypotheses are developed to examine the impact of company-specific characteristics on the level of operating segment required-disclosures. Similar to the prior disclosure literature, the degree of operating segment disclosure is tested using a disclosure index based on the compulsory requirements of IFRS 8. Descriptive statistics show that the average extent of operating segment disclosure in a sample of $150 \mathrm{KSE}$-listed companies in 2013 was 54\%, ranging from 3\% to 95\%. A regression model is used to define which company's specific characteristics are related to the operating segment disclosures. The results revealed that Kuwaiti listed companies with a higher degree of compliance with the IFRS 8-required disclosures (Operating segment) were expected to be larger, highly growth and audited by audit firm associated with a Big-4 audit firm. In contrast with the more compliant, Kuwaiti listed companies with a lesser degree of compliance with the IFRS 8-required operating segment disclosure was likely to be profitable. In contrast, company age, ownership diffusion, leverage and type of industry, were found to be not influencing the compliance with the IFRS 8-required operating segment disclosure.

The outcomes of this research have implications for regulators and potential investors in Kuwait. It affords some feedback to the regulatory and enforcement official bodies about the position of segment disclosure practice of Kuwait listed companies and the factors that may determine the degree of segment disclosures. The differences between the degrees of segment disclosure across companies suggest a need a rigorous system to monitor the compliance with requirements of IFRS 8.

The remainder of this paper is structured as follows. Section 2 overviews the current position of financial reporting regulations in Kuwait. Section 3 discusses the theoretical background, the prior literature and the development of the research hypotheses. Section 4 covers data collection and the sample. Section 5 shows the results of the current research. Finally, Section 6 provide give a brief summary of the study's results and the recommendations.

\section{The Position of Financial Reporting Regulations in Kuwait}

The increase of Kuwaiti companies' activities led to prompt changes in the activities of business environment in Kuwait. This in turn, gives the regulatory official bodies the chance to introduce regulations to deal with the prospective matters that may face (Shuaib, 1978). The significant law governing the financial reporting in 
Kuwait is the Law of Commercial Companies No. 15/1960. This law covers only statutory accounting and auditing rules of the Kuwaiti companies' matters. This law obligates companies to prepare a profit and loss and balance sheet statements. In addition, directors are required to publish their financial statements for the previous financial year, as well as the directors and auditors names, in the official gazette.

Kuwait Commercial Law No. 68/1980 replaced No.2/1961is another law that handles information related to financial reporting in Kuwait. According to this law companies required to keep accounting records in accordance with generally accepted accounting principles. But such principles does not specified. It can be said, that corporate disclosure regulations in Kuwait comprised minimal disclosure requirements. The shortages in above laws, led the Kuwaiti government to adopt the IAS/IFRS.

In this regard, Belkaoui, (1994), pointed out that the many factors for countries to adopt the international accounting standards (IASs). These factors are: participating in the international harmonisation drive, attracting foreign investment, and to cut the setup and production costs. In 1990, Ministerial Resolution No. 18 of 1990 issued by the Ministry of Commerce and Industry (MCI) obligate companies to prepare their financial statements in accordance with the IASs. Noticeably, after the adoption of the IASs, the degree of the information disclosed by companies in Kuwait improved considerably.

In a recent step to improve financial reporting quality and transparency, in 2011, Kuwait established the Capital Market Authority (CMA), an official regulatory body intended to enhance market transparency, increase investor confidence and provide more protection to market participants.

\section{Theoretical Background, Prior Studies and Hypotheses}

\subsection{Theoretical Background}

Besides a country's accounting regulatory and enforcement mechanisms, many theories could explain the financial reporting disclosure decisions and the behaviour of the corporate disclosure level. The current research is therefore based on a combination of the more generally accepted justifications for financial reporting disclosure (theoretical and empirical literature) rather than any particular explanation. Thus, the appropriate theories that explain the behavior of disclosure will be summaries below.

Signalling theory is relevant to the disclosure of accounting information (Watts \& Zimmerman, 1986). It said to arise especially in the information asymmetry, when one party or individual has more information than another about one event (Spence, 1973). Signalling sets out to explain how information asymmetry can be reduced by the actions of the party holding the most information, signalling it to others (Morris, 1987). Those with superior information are thought likely to signal information by disclosing additional information to achieve some economic benefits (Verrecchia, 1983). Based on the signalling assumptions, it can be said that companies whose disclosing segments information according to the IFRS 8 could be sending favourable signals about their willingness to make disclosures to current and potential investors in keeping with what is claimed current best accounting practice, increasing thereby the possibility of access to capital markets and the lowering of the cost of capital.

Agency theory is another theory that could explain the financial reporting disclosure decisions. According to it; management is viewed as the agent and the shareholders as the principal. Corporate managers are perceived to act self-interestedly (Jensen \& Meckling, 1976), the self-interest producing conflicts amongst those involved in the firm (Fama \& Jensen, 1983). Accordingly, agency theory states that the conflict of interests provokes agency costs, which owners then have reason to reduce (Morris, 1987). Agency costs of equity are said to occur when the shareholders observe managers as not pursuing the shareholders' interest and as a result the firm's value declines (possibly mostly reflected by low share prices), and when excessive costs of monitoring and bonding managers so that they do pursue the shareholders' interest, are incurred (Morris, 1987; Healy \& Palepu, 2001). In turn, by virtue of managers having incentives to convince the shareholders that they are taking the right actions, compliance with the operating segment (IFRS 8) is possibly a mechanism by which they might disclose more segment information to moderate the agency costs.

In addition to the signalling and agency theories, proprietary costs theory is also could explain the financial reporting disclosure decisions. Verrecchia (1983) who conducted proprietary costs theory has extensively analyzed the cost of disclosing information. Based on his assumptions, proprietary costs theory is concerned with the impact of disclosure-related costs to limits set by enterprises on the amount of voluntary disclosure to the financial market. According to Berger and Hann (2005) when a segment operates high abnormal earnings "competitors may follow" the company's "business/marketing strategies or enter the specific product markets (within that industry) that the segment operates in". Managers are willing to withhold valuable proprietary 
information out of fear of losing their comparative advantage. Whether proprietary costs did not exist, firms would be motivated to report relevant information. Moreover, the problem of "information asymmetry" which causes conflicts and mistrust among developers and users of financial information would be solved. Verrecchia (1983), states that "the higher the proprietary costs linked to the disclosure, the less negatively investors reach to the withholding of related information, therefore the less perhaps companies voluntarily disclose information".

\subsection{Prior Studies}

Previous literature review has studied the link between company specific-characteristics and the degree of segmental information disclosure. Table 1 summarizes past studies conducted in different countries and indicated to the most significant variables found explain the behavior of segment disclosure practices.

Overall, the above previous studies indicate varied results. The inconsistent outcomes with regard to the company specific-characteristics relationships with the extent of segments disclosure levels could be due to the fact that the prior studies were conducted in different developed and developing markets at different times and among different types of variables. The review of prior studies indicates that only one study (Alfraih \& Alanezi, 2011) discussed company specific-characteristics and the extent of segment reporting under IAS 14 in Kuwait.

The current research is different from the previous one conducted in Kuwait. This study examined the company specific-characteristics relationships with the extent of segments disclosure levels under IFRS 8 (operating segment). However, most prior studies have been conducted in developed countries and examined the association between the levels of segment reporting and company specific-characteristics, such as, ownership diffusion, leverage, size, growth, age, profitability, or audit quality. For instance, Kevin and Zain (2001) test the link between the level of segment disclosure and four firm characteristics: proportion of assets in place, size, earnings volatility and financial leverage. Their outcomes show that only proportion of assets in place and firm size are significant variables influence segment disclosure. Prencipe (2004) indicates that leverage, growth rate, firm age, listing status, firm size, and ownership diffusion are significant variables affect the extent of segment disclosure. In addition, Abu-Serdaneh and Zuriekat (2009) explore the level of segment reporting in Jordanian firms and the firm specific-characteristics that influence the degree of segment disclosure. Their study indicates that companies that have disclosed more segmental information are larger, have less ownership diffusion, and a higher assets-in-place percentage.

Table 1. Past literature review on level of segment reporting disclosure

\begin{tabular}{|c|c|c|c|}
\hline Study & $\begin{array}{l}\text { Number } \\
\text { of Firms }\end{array}$ & Variables tested & Results \\
\hline $\begin{array}{l}\text { Salamon and Dhaliwah (1980) } \\
\text { U.S.A. }\end{array}$ & 51 & Firm size, financial leverage & All significant \\
\hline Bradbury (1992) New Zealand & 29 & $\begin{array}{l}\text { Firm size, financial leverage, proportion of assets in } \\
\text { place, earnings volatility, source of finance }\end{array}$ & Firm size, financial leverage \\
\hline $\begin{array}{l}\text { McKinnon and Dalimunthe } \\
\text { (1993) Australia }\end{array}$ & 65 & $\begin{array}{l}\text { Ownership diffusion, level of minority interest, firm } \\
\text { size, industry, leverage }\end{array}$ & $\begin{array}{l}\text { Firm size, minority level, } \\
\text { ownership diffusion, Industry }\end{array}$ \\
\hline Kelly (1994)-Australia & 150 & Profitability, financial leverage & Profitability \\
\hline Leuz (1999)-Germany & 88 & Firm size, Financial leverage, Profitability & All significant \\
\hline Kevin and Zain (2001) Malaysia & 200 & $\begin{array}{l}\text { Firm size, financial leverage, proportion of assets in } \\
\text { place, earnings volatility }\end{array}$ & $\begin{array}{l}\text { Firm size, proportion of assets } \\
\text { in place }\end{array}$ \\
\hline $\begin{array}{l}\text { Kinsey and Meek (2003) } \\
\text { Developed countries }\end{array}$ & 211 & $\begin{array}{l}\text { Firm size, auditor, country of domicile, industry } \\
\text { international listing status }\end{array}$ & $\begin{array}{l}\text { Firm size, auditors, listing } \\
\text { status, country of domicile }\end{array}$ \\
\hline Prencipe (2004) Italy & 67 & $\begin{array}{l}\text { Firm size, financial leverage, ownership dispersion, } \\
\text { profitability }\end{array}$ & Financial leverage \\
\hline Alsaeed (2006) Saudi Arabia & 72 & $\begin{array}{l}\text { Firm size, debt, liquidity, audit type, ownership } \\
\text { dispersion, profit, Industry, age }\end{array}$ & Firm size, ownership, debt \\
\hline $\begin{array}{l}\text { Abu-Serdaneh and Zuriekat } \\
\text { (2009) Jordan }\end{array}$ & 70 & $\begin{array}{c}\text { Firm size, leverage, earnings volatility, } \\
\text { ownership diffusion, assets- in place }\end{array}$ & $\begin{array}{l}\text { Firm size, ownership, assets-in } \\
\text { place }\end{array}$ \\
\hline $\begin{array}{l}\text { Alfraih and Alanezi (2011) } \\
\text { Kuwait }\end{array}$ & 123 & $\begin{array}{l}\text { Firm size, audit firm, firm age, ownership diffusion, } \\
\text { profitability, leverage, industry }\end{array}$ & $\begin{array}{l}\text { Firm size, firm age, leverage, } \\
\text { profitability, audit firm }\end{array}$ \\
\hline Kumar (2014) India & 125 & $\begin{array}{l}\text { Firm size, leverage, audit, profitability ownership, } \\
\text { growth, market expectation, }\end{array}$ & $\begin{array}{l}\text { Firm size, growth, market } \\
\text { expectation }\end{array}$ \\
\hline
\end{tabular}




\subsection{Hypotheses Development}

Discussion of the literature in the previous section suggested that company specific-characteristics most likely effect the level of compliance with the operating segments (IFRS 8)-required disclosure. To that end, the variables were selected for this study based on the following criteria: (a) they should be statistically measurable; (b) relevant to the Kuwaiti context; and (c) theoretically sound in terms of being linked with the operating segments (IFRS 8)-required disclosures. Eight company-specific variables are selected. These variables are: Company size, company age, ownership diffusion, profitability, leverage, growth, type of auditors and type of industry.

\subsubsection{Company Size}

Several studies have found a positive association between the degree of disclosure and a company's size (for example: Alsaeed, 2005; Owusu-Ansah \& Yeoh, 2005; Barako, Hancock \& Izan, 2006; Chavent, Ding, Stolowy \& Wang, 2006; Alfraih \& Alanezi, 2011; Alfraih \& Almutawa, 2014; Ibrahim \& Jaafar, 2014). A number of theoretical justifications are provided. Disclosing more information is costly, that, large companies can carry such a cost whereas small companies cannot. Therefore, large size companies can disclose more information than small size companies. Another explanation is the competition may describe the association between company size and level of disclosure, since large size companies frequently have numerous financial resources, they can deal with the competition at a cost whereas smaller size companies are more likely not to handle the competition. Thus, small firms are reluctant or incapable to disclose more information than large. Another justification is larger companies are more observable than smaller firms. Therefore, they are exposed to more litigation and government intervention. Thus, larger firms are more willing to disclose information to reduce political costs and mitigate litigation and government intervention. Therefore, it is hypothesized that:

H1: Larger Kuwaiti companies listed on the KSE have greater compliance with the operating segments (IFRS 8)-required disclosure than the smaller Kuwaiti companies listed on the KSE.

\subsubsection{Company Age}

The level of operating segment required-disclosure can be associated with the company age. Older companies might be expected to be more familiar with users' information needs. Therefore, it is expected that the older the company, the longer it has been preparing its annual report in response to the users' information demands, possibly to accord with the IFRSs, the lower the information production and dissemination costs to be sustained. According to Owusu-Ansah (1998), the older the company the more likely it is to comply with the IFRS-required disclosure than younger companies. In contrast, younger companies may suffer competitive disadvantages if they disclose certain items, but older companies did not. The findings of the relationship between company age and the degree of the compliance with the IFRS-required disclosure are not definitive. Al-Shammari et al. (2008) found a positive relationship between company's age and the extent of disclosure while Glaum and Street (2003) found no evidence of such a relationship. Therefore, it is hypothesized that:

H2: Older Kuwaiti companies listed on the KSE are more likely to comply with the operating segments (IFRS 8)-required disclosure than the younger Kuwaiti companies.

\subsubsection{Ownership Diffusion}

Ownership diffusion has been examined in prior studies as a factor that influences disclosure levels. It measured as the ratio of the number of shares owned by outsiders to the number of outstanding shares, In Kuwait, the significant equity ownership ratio in the companies is controlled by insiders such as government and its agencies, merchant and royal families and institutional investors (Al-Shammari et al., 2008). These insiders represented on the companies' boards of directors; thus, able to collect the needed information more than outsiders. If the ownership concentrated by insiders, one can be expected less disclosure. Thus, a negative association is likely to be found between ownership diffusion and the extent of operating segment required-disclosure. Therefore, it is hypothesized that:

H3: The level of operating segment disclosure is negatively linked with a company's ownership diffusion.

\subsubsection{Profitability}

Profitability has been investigated in prior studies as a factor that influence disclosure levels. Many studies claim of a positive relationship between profitability and level of disclosure. Cerf (1961) noted that profitability is one of the dominant management performance measurements, motivating companies' managements to disclose more information to obtain greater remuneration. Also, research by Singhvi and Desai (1971) reported that the companies' managements disclose more information to support the continuation of their own positions and, of course to support claims for greater remuneration. Inchausi (1997) indicated that managers who have 'good news' 
will disclose more information than companies with 'bad news', in order to create a clear, favourable, perception of the value of their companies' shares. Results relating to the association between the profitability and the level of disclosure are not obvious enough and have been mixed. Studies by Singhvi and Desai (1971), Belkaoui and Kahi (1978), Wallace et al. (1994), and Wallace and Naser (1995) pointed out a significant relationship. On the contrary, Cerf (1961), McNally et al. (1982), Meek et al. (1995), Inchausti (1997), and Dumontier and Raffournier (1998) indicate no significant association. Thus, accordingly, it is hypothesized that:

$\mathrm{H} 4$ : The level of operating segments required disclosure is positively associated with a company's profitability.

\subsubsection{Leverage}

Leverage has been proposed as related variable in explaining variation in the level of operating segment required-disclosure. Ahmed (1994) suggests that the agency costs of debt are higher for companies with more debt and that the costs may be reduced by an increased level of disclosure. While increased disclosure may not necessarily be part of a contractual agreement, Wallace et al. (1994) interpret that a higher leveraged company has a greater commitment to suit the needs of its creditors for information and may therefore supply more information than a company with less leverage. Courtis (1979) had found a significant relationship between leverage and the level of disclosure; however, the evidence since has generally not been supportive (e.g. Chow \& Wong-Boren, 1987; Wallace et al., 1994; Raffournier, 1995; Wallace \& Naser, 1995; Inchausti, 1997; Tower et al., 1999). These findings might be that debt holders are in a position to demand, 'negotiate', additional information other than that contained in the annual report and are consequently not as dependent on the disclosures made in it. Therefore, consequently, it is hypothesized that:

H5: Kuwaiti companies with a higher level of leverage in their capital structure are more likely to comply with the operating segments required disclosure.

\subsubsection{Growth}

Growth has been suggested as relevant in explaining variation in the level of operating segment required-disclosure. Prencipe (2004) argues that the potential competitive costs arising from disclosing segment information tend to be particularly high for growing firms, as competitors could use this information to the detriment of growing firms. Similarly, Chavent et al. (2006) found that growing firms are more likely to conceal sensitive information, because full disclosure may jeopardize their competitive positions. Therefore, a negative link between a firm's growth and degree of segment disclosure is likely to be found. Consequently, it is hypothesized that:

H6: The level of operating segment required- disclosure is negatively associated with a company's growth.

\subsubsection{Type of Auditor}

Type of auditor has been proposed as a significant factor explaining the variation in the level of disclosure. The association between financial disclosure degree and the type of external auditing firms is greatly investigated in the literature (Palmer, 2008). The literature has delivered some reasons for the positive association between disclosure degree and the external audit type. DeAngelo (1981) argues that larger auditing firms are fearful to lose their reputations and, thus, have more to lose if they not report errors or misrepresentations in their clients' annual reports. Malone et al. (1993) state that because losing a client has an economic consequence on smaller auditing firms and thus are sensitive to their clients' demands. Wallace and Naser (1995) argue that, larger auditing firms are less likely to depend on one or a few clients and thus, are willing to deliver greater disclosure in their clients' annual reports (Wallace \& Naser, 1995). Wallace et al. (1994) argue that audit firms affiliated with Big-4 audit firms are more likely to provide more detailed information than firms audited not affiliated with Big-4 audit firms. The justification is that Big-4 audit firms is larger and offer more expertise than local audit firms. Therefore, it is hypothesised that:

H7: The level of operating segment required-disclosure is positively associated with being audited by audit firm associated with a Big-4 auditing firm.

\subsubsection{Type of Industry}

Consistent with the size hypothesis, since, large companies might be expected to seek funds from different resources, Kuwaiti joint-stock companies in large sectors might be expected to comply with the IFRSs more than in the small sectors. Wallace et al. (1994) pointed out that companies from a specific sector might implement voluntary disclosure, in addition to the general compulsory disclosure practices for all companies. Large companies are likely to be in dominant industries, though it is also likely that small companies are likely to be in infant industries requiring a good disclosure image to attract finance. Not surprisingly, the results regarding the 
relationship between the degree of disclosure and type of industry have varied. Stanga (1976); Belkoui and Kahl (1978); Cooke (1991, 1992); and Wallace and Naser (1995) indicated a significant relationship between the level of disclosure and the type of industry. In contrast, studies by Wallace (1987); Raffournier (1995); Patton and Zelenka (1997) indicated no significant association between the industry type and the degree of disclosure. Accordingly, it is hypothesized that:

H8: The level of operating segment-required disclosure among Kuwaiti industries is different.

\section{Research Design and Method}

\subsection{Population, Sample, and Data Collection}

Since all Kuwaiti companies listed on the KSE no matter what their activities must comply with IFRS 8 (operating segments) disclosure requirements in accordance with Kuwaiti Ministerial Resolution No. 18 of 1990, the population of this study for measuring operating segment disclosure consists of all the Kuwaiti companies listed on the KSE in 2013.

Three sources were consulted to collect the data: (i) The annual reports for year 2013 of Kuwaiti companies listed on the KSE which were the most recent data available; (ii) the Kuwait Stock Exchange Investor Guide (KSEIG) for year 2013; and (iii) the KSE' official website. According to the KSEIG, by the end of 2013, 187 Kuwaiti companies were listed on the KSE. However, it should be noted that the selection of companies in the sample is based on the applicability of operating segments disclosure requirements to the company. 37 companies are not relevant to this study and excluded from the study sample. Therefore, the sample consists of 150 KSE-listed companies. Table 2 shows the industry classification of sample companies included in this study and their percentages relative to the entire sample population.

Table 2. Number of Kuwaiti companies at the end of 2013 and the sample size

\begin{tabular}{cccc}
\hline Industry Classification & No. of companies at the end of 2013 & No. of companies in the sample & $\%$ \\
\hline Financial & 19 & 14 & $9 \%$ \\
(Banks and Insurance) & 40 & 33 & $22 \%$ \\
Investment & 37 & 31 & $21 \%$ \\
Real Estate & 35 & 29 & $19 \%$ \\
$\quad$ Industrial & 56 & 43 & $29 \%$ \\
(Industry and Food) & 187 & 150 & $100 \%$ \\
Service & & & \\
Total & &
\end{tabular}

\subsection{The Dependent Variable-Extent of Operating Segment Disclosure}

The dependent variable in this study is the level of operating segment disclosure. An Operating Segment Disclosure Index (OSDI) was developed based on IFRS 8 required disclosures. In constructing and developing the OSDI, the official International Accounting Standard Board (IASB) volume for 2013 (IASB, 2013) is used to obtain details about IFRS 8 required disclosures. The OSDI is constructed to specifically address the required disclosures of IFRS 8. Operating segment Items that are clearly voluntary or merely optional by the IASB are not included in the OSDI. From IFRS 8, 50 required disclosure items are obtained and set out in the constructed OSDI (Appendix A). It should be noted that a preliminary version of the operating segment disclosure items checklist was reviewed by Kuwaiti professionals from accounting firms and academics from Kuwait University and the Public Authority for Applied Education and Training-who offered their opinions with regard to the inclusion and exclusion of information items in the checklist. Following prior studies on scoring the index (Tower et al., 1999; Street \& Gray, 2002; Street \& Bryant, 2000; Haniffa \& Cooke, 2002; Glaum \& Street, 2003; Ali et al., 2004; Al-Shammari et al., 2008; Alfraih \& Alanezi, 2011; Alanezi et al., 2012; Alfraih \& Almutawa, 2014), an item of information was assigned " 1 " if it is clearly disclosed, " 0 " if it is clearly not, and the conventional "N/A" if it is clearly not applicable.

Higher scores on the OSDI refer to the greater degree of operating segment disclosure; the OSDI represents the dependent variable in the regression models. Operationally, the OSDI for a given company was computed as a ratio by calculating the total number of operating segment required disclosures made by its annual report, divided by the maximum relevant score.

Consistent with the related literature (Tower et al., 1999; Street \& Bryant, 2000; Haniffa \& Cooke, 2002; Street \& 
Gray, 2002; Glaum \& Street, 2003; Ali et al., 2004; Al-Shammari et al., 2008; Alfraih \& Alanezi, 2011; Alanezi et al., 2012), equal weight was attached to items in the OSDI, on the grounds that IFRS 8- required disclosure items are equally important to all users.

\subsection{The Independents Variables-Determinants of Operating Segment Disclosures}

Company specific-characteristics are used as variables explaining the variation of the operating segment disclosures level in this study. Information regarding company age, industry categories, and ownership diffusion were obtained from the official KSE's Web site. Data related to firm size, audit type, profitability, leverage, and growth were extracted from the companies' financial statements. Table 3 presents definitions of all specific company characteristics used in this study as determinants of operating segment required disclosures.

Table 3. Definition of company-specific characteristics (independent variables)

\begin{tabular}{|c|c|}
\hline Independent Variable & Operationalization \\
\hline Company size & The log of total assets \\
\hline Audit type & $\begin{array}{c}\text { Dummy variable coded } 1 \text { if one Big- } 4 \text { audit firm audits the company's financial statements } \\
\text { and } 0 \text { otherwise }\end{array}$ \\
\hline Company age & The log of number of years passed since established \\
\hline Ownership diffusion & Number of shares owned by outsiders / number of outstanding shares at year-end \\
\hline Profitability & Return on equity (ROA) \\
\hline Leverage & The log of total debt / total shareholders equity \\
\hline Growth & The log of growth in sales over the previous fiscal year \\
\hline Industry & $\begin{array}{l}\text { Dummy variable that equals } 1 \text { for firms in the financial institutions (banks \&insurance) } \\
\text { category and } 0 \text { otherwise (industry } 1 \text { ); dummy variable that equals } 1 \text { for firms in the } \\
\text { investment category and } 0 \text { otherwise(industry } 2 \text { ); dummy variable that equals } 1 \text { for firms in } \\
\text { the real estate category and } 0 \text { otherwise (industry } 3 \text { ); dummy variable that equals } 1 \text { for firms } \\
\text { in the industrial (manufacturing \& food) category and } 0 \text { otherwise (industry } 4 \text { ); dummy } \\
\text { variable that equals } 1 \text { for firms in the services category and } 0 \text { otherwise (industry } 5 \text { ) }\end{array}$ \\
\hline
\end{tabular}

\subsection{Model Specification}

In order to test the study hypotheses, a multiple regression model was used using ordinary least squares (OLS) to determine which company specific-characteristics are associated with the operating segment (IFRS 8)-required disclosure and their significance level. Thus, the following regression model was fitted to the data.

$$
\begin{gathered}
Y=\beta_{0}+\beta_{1}(\text { company size })+\beta_{2}(\text { audit type })+\beta_{3}(\text { company age })+\beta_{4}(\text { ownership diffusion })+ \\
\beta_{5}(\text { profitability })+\beta_{6}(\text { leverage })+\beta_{7}(\text { growth })+\beta_{8-11}\left(\text { industry }_{1-4}\right)+\varepsilon
\end{gathered}
$$

where, $\mathrm{Y}=$ operating segment disclosure score; $\beta_{0}=$ regression intercept, the other ${ }^{\beta} \mathrm{s}$ are the parameters of the Model.

\section{Results}

\subsection{Descriptive Statistics}

Table 4 presents descriptive statistics for Operating Segment Disclosure Index (OSDI). The table shows that the mean for the OSDI of a sample of KSE-listed companies in 2013 was 0.54 , with a minimum score of 0.03 and a maximum of 0.95 . These outcomes suggest that operating segment disclosure levels among the 150 sample companies were widely distributed and varied. This variation affords to test the company specific characteristics that affect the level of operating segment disclosures.

Table 4. Descriptive statistics for the operating segment disclosure index (OSDI)

\begin{tabular}{cccccc}
\hline Dependent Variable & $\mathrm{N}$ & Mean & Min & Max & Standard Deviation \\
\hline OSDI & 150 & 0.54 & 0.03 & 0.95 & 0.18 \\
\hline
\end{tabular}

Note. OSDI = Operating Segment Disclosure Index

Table 5 presents the descriptive statistics for the independent continuous and dummy variables used in this study. 
A significant degree of variation exists in firm size as shown in Panel A. Firm size ranges from KD 5.00 million to KD 18600.00 million, with a mean of 620.45 million and a median of 85.50 million. Due to the non-normality, firm size was transformed using the natural logarithm of total assets as of December 31, 2013. In addition, Panel A of Table 5 shows that the age of companies examined in this study ranged from 9 to 62 years, with a mean of 26.6 years and a median of 21 years. Due to the non-normality, company age was transformed using the natural logarithm of company age since established. Ownership diffusion ranges from 0.01 to 1.00 , with a mean of 0.46 and firm profitability varies from -0.21 to 0.24 , with a mean of 0.04 . In addition, the descriptive statistics presented in Panel A shows that firm leverage ranges from 0.00 to 0.88 , with a mean of 1.39. Leverage was transformed using the natural logarithm of total debt/total shareholders equity, and firm growth range from -3.29 to 260.22 , with a mean of 1.78 . Growth was transformed using the natural logarithm of growth in sales over the previous fiscal year. Panel B of Table 5 presents the distribution of companies that were audited by audit firm associated with Big-4 and audit firms not associated with Big- 4 . The results reveal that $62 \%$ of the companies included in the study were audited by audit firm associated with Big-4, while $38 \%$ of the companies were audited by audit firms not associated with Big-4.

Table 5. Descriptive statistics for independent continuous and dummy variables

\begin{tabular}{cccccc}
\hline Panel A: Independent Variable & Mean & Median & Standard Deviation & Minimum & Maximum \\
\hline LCO.SIZE & 620.45 & 85.50 & 2261.70 & 5.00 & 18600.00 \\
CO.AGE & 26.60 & 21.00 & 13.70 & 9 & 62 \\
OWNERSHIP & 0.45 & 0.44 & 0.22 & 0.01 & 1.00 \\
PROFIT & 0.04 & 0.04 & 0.07 & -0.21 & 0.24 \\
LLEVERAGE & 1.39 & 0.31 & 7.21 & 0.00 & 87.70 \\
LGROWTH & 1.78 & 0.01 & 21.26 & -3.29 & 260.22 \\
\hline Panel B: Dummy Variable & Frequency & Percent $(\%)$ & & & \\
\hline Auditor Quality & & & & & \\
Big-4 & 93 & 62 & & & \\
Non-Big-4 & 57 & 38 & & & \\
Total & 150 & 100 & & & \\
\hline
\end{tabular}

Note. SIZE is the amount of firms' total assets (KD million) at the end of 2013; AGE is the number of years passed since established to the end of 2013; OWNERSHIP diffusion is measured by number of shares owned by outsiders / number of outstanding shares at year-end; PROFIT is the Return on Assets (ROA) for the year ended 31 December, which is the ratio of net income to average common shareholders' equity; LEVERAGE is the ratio of total debt to total shareholders' equity at the end of 2013, and GROWTH is the growth in sales over the previous fiscal year.

\subsection{Bivariate Relationships between the Variables}

Two tests were undertaken to examine multicollinearity between independent variables: first, the Pearson Correlation Matrix for the independent continuous variables, and second, computing the variance inflation factor (VIF). The correlations among the continuous independent variables are reported in Table 6. The results showed that no pair-wise correlation coefficient is in excess of 0.80 , thus suggesting that multicollinearity is not likely to be a serious problem in interpreting the multiple regression results (Gujarati, 2003).

Table 6. Person correlation coefficients matrix for the continuous independent variables

\begin{tabular}{cccccccc}
\hline Variables & Co. Size & Co. Age & Ownership & Profitability & Leverage & Growth \\
\hline L. Co. Size & 1.00 & & & & & \\
L. Co. Age & $.345^{* *}$ & 1.00 & & & & \\
Ownership & $.164^{*}$ & .053 & 1.00 & & & \\
Profitability & .098 & -.061 & -.143 & 1.00 & & \\
L. Leverage & $.225^{* *}$ & -.005 & $.182^{*}$ & .005 & 1.00 & \\
L. Growth & -.067 & -.158 & .072 & $-.179^{*}$ & .026 & 1.00 \\
\hline
\end{tabular}

Note. ** Significant at the 0.01 level (two-tailed). * Significant at the 0.05 level (two-tailed). 
The Variance Inflation Factor (VIF) test is another assessment used in this study to test multicollinearity. The VIF values presented in Table 7 do not raise concern regarding multicollinearity among variables because the VIF value for each independent variable do not exceed the suggested VIF of 10 in the model (Belsley et al., 1980; Neter et al., 1996). Accordingly, multicollinearity did not appear to be a serious problem in interpreting the regression results of this study.

Table 7. Variance inflation factors (VIF) for all independent variables

\begin{tabular}{cc}
\hline Independent Variables & Variance Inflation Factors (VIF) \\
\hline L. SIZE & 1.592 \\
L. AGE & 1.314 \\
OWNERSHIP & .156 \\
PROFITABILITY & 1.202 \\
L. LEVERAGE & 1.229 \\
L. GROWTH & 1.240 \\
AUDIT TYPE & 1.201 \\
INDUSTRY 1financial institutions & 1.780 \\
INDUSTRY 3 real estate & 1.576 \\
INDUSTRY 4 industrial & 1.846 \\
INDUSTRY 5 services & 1.881 \\
\hline
\end{tabular}

\subsection{Regression Analysis}

This paper is examined the association between the level of operating segment-required disclosure and eight specific company characteristics of sample Kuwaiti companies listed on the KSE in 2013. Table 8 reports the multiple regression model results. The results reveal that the regression model, which attempts to explain variation in the operating segment disclosure level in term of company characteristics, is significant $(F=5.910$, $p<0.000$ ). The $R^{2}$ (adj.) indicates that approximately 27 percent of the operating segment required disclosure level variation is explained by the independent variables used in this study. The explanatory power of this model is higher than (Alfraih \& Alanezi, 2011) 23 percent and (Ibrahim \& Jaafar, 2014) 20 percent.

The outcomes indicated that the level of operating segment required-disclosure was associated with company size, type of auditors and growth. However, company age, ownership diffusion, leverage and industry type were not significant while profitability was significant but in the opposite prediction. The results show that company size is a significant factor in explaining the variations in operating segment required-disclosure levels among KSE-listed companies $(p<0.01)$. This result is support hypothesis $1(\mathrm{H} 1)$. This outcome is consistent with Alfraih and Alanezi (2011) and Ibrahim and Jaafar (2014). A likely justification for this finding is that larger companies are more willing to disclose information to reduce political costs and mitigate litigation and government intervention. In addition, the cost associated with accumulating information is lower for larger firms because of their extensive internal reporting systems. In comparison, smaller firms are more likely to conceal sensitive information because full disclosure could jeopardize their competitive positions (Chavent et al., 2006).

As predicted in hypothesis 7 (H7), the results in Table 8 show that the operating segment required-disclosure level is associated positively with the auditor type $(p<0.01)$. This result is consistent with Alfraih and Alanezi (2011). A possible explanation for this finding is that KSE companies that are audited by a Big-4 auditing firm tend to have a higher level of segment disclosures than firms audited by a non-Big-4 auditing firm. This result confirms the notion of Wallace et al. (1994) that firms audited by internationally affiliated audit firms - the Big-4-are more likely to provide more detailed information than are firms audited by local audit firms. This is because the internationally affiliated audit firms are larger and backed by more expertise than are local audit firms (Wallace et al., 1994).

Company growth is found to be significantly associated with the operating segment required-disclosure $(p<$ 0.01). Thus, hypothesis 6 (H6), that operating segment required-disclosure is negatively associated with company growth is supported. A possible explanation for this finding is that the potential competitive costs arising from disclosing segment information tend to be particularly high for growing companies, as competitors could use this information to the detriment of growing companies (Prencipe, 2004).

The results in Table 8 show that the level of operating segment required-disclosure is negatively and significantly associated with company profitability $(\mathrm{p}<0.01)$. It is opposite to the prediction. Therefore, hypothesis $4(\mathrm{H} 4)$ is 
not supported. This finding supports the argument that company generate profit could generate a substantial increase of proprietary costs and as a result disclose less information. This result consistent is with Prencipe (2004).

Table 8. Multivariate regression analysis results

\begin{tabular}{|c|c|c|c|c|c|}
\hline Variable & Predicted Sign & Coefficient & & $t$-statistic & \\
\hline Intercept & & 0.034 & & 2.144 & \\
\hline L.SIZE & + & 0.006 & & $2.767+++$ & \\
\hline L.AGE & + & 0.179 & & -1.350 & \\
\hline OWNERSHIP & + & 0.603 & & -.521 & \\
\hline PROFITABILITY & + & 0.019 & & $-2.373+++$ & \\
\hline L.LEVERAGE & + & 0.814 & & -.235 & \\
\hline L. GROWTH & - & 0.007 & & $-2.752+++$ & \\
\hline AUDIT TYPE & + & 0.000 & & $5.087+++$ & \\
\hline IND_FININ & $?$ & 0.980 & & -.026 & \\
\hline IND_IVEST & $?$ & 0.132 & & -1.516 & \\
\hline IND_INDUS & $?$ & 0.338 & & -.961 & \\
\hline IND_SERV & $?$ & 0.690 & & -.400 & \\
\hline $\mathrm{N}$ & $\mathrm{R}^{2}$ & Adj. $R^{2}$ & $F$-statistic & & $p$-value ( $F$-statistics) \\
\hline 150 & 0.320 & 0.266 & 5.910 & & 0.000 \\
\hline
\end{tabular}

Note. +++ significant at the 0.01 levels respectively (one-tailed)

OSDI is the ratio of a firm's actual segment disclosure score to the maximum segment score that the firm is expected to achieve if the firm fully complies with the operating segment required-disclosure of the IFRS 8; LSIZE is the natural logarithm of total assets at the end of 2013; AUDIT is a dummy variable coded 1 if one Big-4 audit firm audits the firm's financial statements and 0 otherwise; AGE is the number of years passed since foundation to the end of 2013; OWNERSHIP diffusion is measured by number of shares owned by outsiders / number of outstanding shares at year-end; PROFIT is the Return on Equity (ROE) for the year ended 31 December, which is the ratio of net income to average common shareholders' equity; LEVERAGE is the ratio of total debt to total shareholders' equity at the end of 2013 and GROWTH is the growth in sales over the previous fiscal year; IND_FT is a dummy variable that equals 1 for firms in the Financial Institutions category, and 0 otherwise; IND_INVST is a dummy variable that equals 1 for firms in the Investment category, and 0 otherwise; IND_INDUS is a dummy variable that equals 1 for firms in the Industrial category, and 0 otherwise; IND_SERV is a dummy variable that equals 1 for firms in the Service category, and 0 otherwise (the omitted industry category when all categories are 0 is the Real Estate category).

OSDI $=\beta_{0}+\beta_{1}$ (company size) $+\beta_{2}$ (audit type $)+\beta_{3}$ (company age $)+\beta_{4}$ (ownership diffusion $)+\beta_{5}$ (profitability) $+\beta_{6}($ leverage $)+\beta_{7}$ (growth) $+\beta_{8-11}\left(\right.$ industry $_{1-4)}+\varepsilon$

In contrast, an insignificant positive association is observed for company age. Thus, hypothesis $2(\mathrm{H} 2)$, that operating segment required-disclosure is positively associated with company age, is not supported. Similarly, ownership diffusion is found to be insignificantly associated with operating segment required-disclosure. Thus, hypothesis 3 (H3), that operating segment required-disclosure is negatively associated with ownership diffusion, is not supported. Leverage is found to be insignificantly associated with operating segment required-disclosure. Thus, hypothesis 5 (H5), that operating segment required-disclosure is positively associated with leverage, is not supported. Industry types were used as control variables. For control variables, the results show that industry types do not significantly influence segment disclosures. Thus, hypothesis 8 (H8), that operating segment required-disclosure among Kuwaiti industries is different, is not supported.

\section{Conclusions and Implications}

The objective of the study was to evaluate the operating segment disclosure practice of KSE-listed companies as well as the impact of particular company specific characteristics on their level of operating segment required-disclosure (IFRS 8). Based on the IFRS 8, an OSDI based on 50 items was developed to investigate the level of segment disclosure in the 2013 annual reports of a sample of 150 Kuwaiti-listed companies. The results show that the average level of operating segment required-disclosure compliance of the Kuwaiti companies included in this study was 54 per cent, with a high of 95 per cent and a low of 3 per cent. These statistical results reflect their widely distributed patterns with regard to the levels of the operating segment required-disclosure. 
Multivariate regression analysis revealed that the company size, type of auditors, growth and profitability were the most important variables explaining the KSX-listed Kuwaiti companies' compliance with IFRS disclosure practices. In contrast, company age, ownership diffusion, leverage and industry type did not emerge as being statistically significant in explaining the operating segment-required disclosures.

In general, the results of the statistical analysis are mixed. Thus, the results revealed that Kuwaiti companies with a higher level of compliance with the operating segment-required disclosures are big size and audited by audit firms affiliated with Big-4. In addition, there were not significant differences across industries in the level of compliance with the operating segment-required disclosures. In contrast with the more compliant, Kuwaiti companies with a lower level of compliance with the operating segment-required disclosure are likely to be have high growth and profitable.

These results have implications and suggestions for policy makers. In the present Kuwaiti disclosure and regulatory climate, users of corporate financial disclosures in Kuwait might reasonably expect fuller compliance with IFRS required disclosures from big size companies and audited by audit firms affiliated with Big-4 audit firm. Contrariwise, high growth and profitable companies are negatively and significantly associated with IFRS-required disclosures. The examination of the relationship between particular company specificcharacteristics such as company size and type of auditors and the extent of the IFRS-required disclosure, provides an insight into those factors that assist in the explanation of the variability in, and the extent of, IFRS-required disclosures by Kuwaiti companies. Such an addition to knowledge may assist in remedying deficiencies. This study is providing an assessment of the degree of operating segment required-disclosure among KSE-listed companies and the factors that could influence the level of operating segment disclosure. The findings of this study offer some feedback to the regulatory and enforcement bodies in Kuwait about the current segment disclosure practice of KSE-listed firms and the factors that influence the level of segment disclosures. The clear variation in the extent of segment disclosure across listed companies suggests a need for a strong monitoring and enforcement system to monitor companies not compliance with the requirements of segment disclosure.

This study has limitations. First, the conclusions drawn are subject to an unavoidably small sample size as the KSE is a relatively small market. Second, this study has been a cross-sectional examination, thus, a longitudinal study will be needed to obtain a fuller understanding and greater insight. Third, the subjectivity inherent in scoring the disclosures by the sample companies on the OSDI is clearly a matter of concern. But the procedures adopted in this study mirror those used in similar studies of disclosure in more sophisticated market settings, and have been taken to be a serviceable means of gaining a quantitative insight into the level of corporate disclosure. Fourth, the possibility always exists that the study may have omitted other factors that would help explain this variation, such as corporate governance quality. In addition, it would be interesting to analyze segment disclosure under IFRS 8 (Operating Segments) that replace IAS 14 and examine whether segment disclosures have improved under IFRS 8.

\section{References}

Abu-Serdaneh, J., \& Zuriekat, M. (2009). Segment Reporting in Jordanian Listed Companies. Arab Journal of Administrative Sciences, 16(3), 489-516.

Ahmed, K. (1994). An Empirical Study of Corporate Disclosure Practices in Bangladesh. Accounting Forum, $18(2), 38-56$.

Alanezi, F. (2006). An empirical study of Kuwaiti joint-stock companies' compliance with the International Financial Reporting Standards (Doctoral dissertation). Callaghan, NSW: University of Newcastle.

Alanezi, F., Alfraih, M., Alrashaid, E., \& Albolushi, S. (2012). Dual/Joint Auditors and the Level of Compliance with International Financial Reporting Standards (IFRS-required disclosure): The Case of Financial Institutions in Kuwait. Journal of Economic and Administrative Sciences, 28(2), 109-129. http://dx.doi.org/10.1108/10264111211248402

Alfraih, M., \& Alanezi, F. (2011). What Explains Variation in Segment Reporting? Evidence from Kuwait. The International Business \& Economics Research Journal, 10(7), 31-45.

Alfraih, M., \& Almutawa, A. (2014). The Association between Firm-Specific Characteristics and Corporate Financial Disclosure: Evidence from an Emerging Market. International Journal of Accounting and Taxation, 2(3), 55-78. http://dx.doi.org/10.15640/ijat.v2n3a4

Al-Shammari, B., Brown, P., \& Tarca, A. (2008). An Investigation of Compliance with International Accounting Standards by Listed Companies in the Gulf Co-Operation Council Member States. The International 
Journal of Accounting, 43, 425-447. http://dx.doi.org/10.1016/j.intacc.2008.09.003

Ali, M., Ahmed, K., \& Henry, D. (2004). Disclosure compliance with national accounting standards by listed companies in South Asia. Accounting and Business Research, 34(3), 183. http://dx.doi.org/ $10.1080 / 00014788.2004 .9729963$

Alsaeed, K. (2006). The association between firm-specific characteristics and disclosure. Managerial Auditing Journal, 21(5), 476. http://dx.doi.org/10.1108/02686900610667256

Association for Investment Management and Research (AIMR). (1993). Financial Reporting in 1990s and Beyond: A Position Paper of the Association for Investment Management and Research. Financial Accounting Policy Committee,Prepared by Peter H. Knuston. Charlottesville, VA: AIMR.

Barako, D., Hancock, P., \& Izan, H. Y. (2006). Factors Influencing Voluntary Corporate Disclosure by Kenyan Companies. Corporate Governance: An International Review, 14(2), 107-125. http://dx.doi.org/10.1111/j.1467-8683.2006.00491.x

Belkaoui, A. (1994). Accounting in the Developing Countries. Quorum Books, U.S.A.

Belkaoui, A., \& Kahl, A. (1978) Corporate financial disclosure in Canada. Research Monograph, No. 1, Vancouver: Canadian Certified General Accountants Association.

Belsley, D., Kuh, E., \& Welsch, R. (1980). Regression Diagnostics: Identification Influential Data and Sources of Collinearity. New York: John Wiley \& Sons, Inc.

Berger, P., \& Hann, R. (2005). The Impact of SFAS No. 131 on Information and Monitoring. Journal of Accounting Research, 41(2), 163-163-223. http://dx.doi.org/10.1111/1475-679X.00100

Birt, J., Kend, M., \& Xian, H. (2007). Changes in Segment Reporting in the Australian Banking Industry. Australian Accounting Review, 17(3), 61-67. http://dx.doi.org/ 10.1111/j.1835-2561.2007.tb00337.x

Bradbury, M. E. (1992). Voluntary Disclosure of Financial Segment Data: New Zealand Evidence. Accounting and Finance, 15-26. http://dx.doi.org/10.1111/j.1467-629X.1992.tb00174.x

Cerf, R. A. (1961). Corporate reporting and investment decisions. California:The University of California Press.

Chavent, M., Ding, Y., Fu, L., Stolowy, H., \& Wang, H. (2006). Disclosure and determinants studies: An extension using the Divisive Clustering Method (DIV). European Accounting Review, 15(2), 181. http://dx.doi.org/10.1080/09638180500253092

Chow, C. W., \& Wong-Boren, A. (1987). Voluntary Financial Disclosure by Mexican Corporations. Accounting Review, 62(3), 533-541.

Cooke, T. E. (1991). An Assessment of Voluntary Disclosure in the Annual Reports of Japanese Corporations. International Journal of Accounting, 26(3), 174-189.

Cooke, T. E. (1992). The Impact of Size, Stock Market Listing and Industry Type on Disclosure in the Annual Reports of Japanese Listed Corporations. Accounting and Business Research, 22(87), 229-237. http://dx.doi.org/10.1080/00014788.1992.9729440

Courtis, J. K. (1979). Annual Report Disclosure in New Zealand: Analysis of Selected Corporate Attributes. New England Accounting Research Study No. 8: University of New England.

DeAngelo, L. (1981). Auditor Size and Audit Quality. Journal of Accounting and Economics, 3(3), 183-199. http://dx.doi.org/10.1016/0165-4101(81)90002-1

Dumontier, P., \& Raffournier, B. (1998). Why Firms Comply Voluntarily with IAS: An Empirical Analysis with Swiss Data. Journal of International Financial Management and Accounting, 9(3), 216-245. http://dx.doi.org/10.1111/1467-646X.00038

Epstein, M., \& Palepu, K. (1999). What financial analysts want. Strategic Finance, 80(10), 48-52.

Fama, E. F., \& Jensen, M. C. (1983). Separation of Ownership and Control. Journal of Law and Economics, 25(June), 301-325.

Glaum, M., \& Street, D. L. (2003). Compliance with the Disclosure Requirements of Germany's New Market: IAS Versus US GAAP. Journal of International Financial Management \& Accounting, 14(1), 64-100. http://dx.doi.org/10.1111/1467-646X.00090

Gujarati, D. N. (2003). Basic Econometrics (3rd ed.). New York: McGraw-Hill, Inc.

Haniffa, R. M., \& Cooke, T. E. (2002). Culture, corporate governance and disclousure in Malaysian corporations. 
Abacus, 38(3), 317. http://dx.doi.org/10.1111/1467-6281.00112

Healy, P., \& Palepu, K. (2001). Information asymmetry, corporate disclosure, and the capital markets: A review of the empirical disclosure literature. Journal of Accounting \& Economics, 31(1-3), 405. http://dx.doi.org/10.1016/S0165-4101(01)00018-0

IASB. (2013). International Financial Reporting Standards Incorporating International Accounting Standards and Interpretations. London: International Accounting Standards Board.

Ibrahim, K., \& Jaafar, H. (2014). Corporate Governance and Disclosure on Segment Reporting: Evidence from Nigeria. Global Review of Accounting and Finance, 5(2), 98-113.

Inchausti, B. (1997). The influence of company characteristics and accounting regulation on information disclosed by Spanish firms. The European Accounting Review, 6(1), 45-68. http://dx.doi.org/10.1080/096381897336863

Jensen, M., \& Meckling, W. (1976). Theory of the Firm: Managerial Behavior, Agency Costs and Ownership Structure. Journal of Financial Economics, 3(3), 305-360.

Kelly, G. J. (1994). Unregulated segment reporting: Australian evidence. British Accounting Review, 26, 217-234. http://dx.doi.org/10.1006/bare.1994.1015

Kevin, L., \& Zain, M. (2001). Segmental Reporting: An Insight Into Malaysia's Companies. SSRN eLibrary.

Kinsey, P. J., \& Meek, G. K, (2004). The effect of revised IAS 14 on segment reporting by IAS companies. European Accounting Review, 13(2), 215. http://dx.doi.org/10.1080/0963818032000138206

KSE. (2013). Investor guide. Kuwait Stock Exchange Bulletins.

Kumar, F. (2014). The effect of Firm-Specific Characteristics on Segment Information Disclosure: A Case of Indian Listed Companies. International Journal of Management, 5(9), 41-48.

Leuz, C. (1999). Voluntary Disclosure of Cash Flow Statements and Segment Data in Germany. Working Paper Series: Finance \& Accounting, 21, 1-46.

Malone, D., Fries, C., \& Jones, T. (1993). An empirical investigation of the extent of corporate financial disclosure in the oil and gas industry. Journal of Accounting, Auditing \& Finance, 8(3), 249. http://dx.doi.org/ 10.1177/0148558X9300800306

McKinnon, J. L., \& Dalimunthe, L. (1993). Voluntary disclosure of segment information by Australian $\begin{array}{llll}\text { diversified } & \text { companies. } & \text { Accounting and }\end{array}$ http://dx.doi.org/10.1111/j.1467-629X.1993.tb00192.x

McNally, G. M., Eng, L. H. \& Hasseldine, R. (1982). Corporate Financial Reporting in New Zealand: An Analysis of User Preferences, Corporate Characteristics and Disclosure Practices for Discretionary Information. Accounting and Business Research, 12(46), 11-20. http://dx.doi.org/10.1080/00014788.1982.9729725

Meek, G. K., Roberts, C. B., \& Gray, S. J. (1995). Factors Influencing Voluntary Annual Report Disclosures by US, UK and Continental European Multinational Corporations. Journal of International Business Studies, 26(3), $555-572$.

Morris, R. D. (1987). Signalling, Agency Theory And Accounting Policy Choice. Accounting and Business Research, 18(69), 47. http://dx.doi.org/10.1080/00014788.1987.9729347

Neter, J., Kutner, M. H., Nachtscheim, C. J., \& Wasserman, W. (1996). Applied Linear Statistical Models. Boston, MA: McGraw-Hill.

Owusu-Ansah, S. (1998). The impact of corporate attributes on the extent of mandatory disclosure and reporting by listed companies in Zimbabwe. The International Journal of Accounting, 33(5), 605. http://dx.doi.org/10.1016/S0020-7063(98)90015-2

Owusu-Ansah, S., \& J. Yeoh. (2005). The Effect of Legislation on Corporate Disclosure Practices. Abacus, 41(1), 92-109. http://dx.doi.org/10.1111/j.1467-6281.2005.00171.x

Palmer, P. (2008). Disclosure of the impacts of adopting Australian equivalents of International Financial $\begin{array}{lllll}\text { Reporting Standards. Accounting \& } & \text { Finance, } & 48(5), 870 .\end{array}$ http://dx.doi.org/10.1111/j.1467-629X.2008.00262.x

Patton, J., \& Zelenka, I. (1997). An Empirical Analysis of the Determinants of the Extent of Disclosure in Annual Reports of Joint Stock Companies in the Czech Republic. European Accounting Review, 6(4), 605-626. 
http://dx.doi.org/10.1080/09638189700000003

Prather-Kinsey, J., \& Meek, G. (2004). The effect of revised IAS 14 on segment reporting by IAS companies. European Accounting Review, 13(2), 213. http://dx.doi.org/10.1080/0963818032000138206

Prencipe, A. (2004). Proprietary costs and determinants of voluntary segment disclosure: Evidence from Italian listed companies. European Accounting Review, 13(2), 319-340. http://dx.doi.org/10.1080/0963818042000204742

Raffournier, B. (1995). The Determinants of Voluntary Financial Disclosure by Swiss Listed Companies. European Accounting Review, 4(2), 261-280. http://dx.doi.org/10.1080/09638189500000016

Salamon, G. L., \& Dhaliwal, D. S. (1980). Company size and financial disclosure requirements with evidence from the segmental reporting issue. Journal of Business Finance and Accounting, 7(4), 555-568. http://dx.doi.org/10.1111/j.1468-5957.1980.tb00221.x

Saudagaran, S. M. (2004). International Accounting: A user perspective (2nd ed). Ohio: South-Western College Publishing.

Shuaib, S. (1978). The Middle East: Accounting in Kuwait and Banker's View of Business Opportunities in the Area. The Journal of Accountancy, 74-79.

Singhvi, S., \& Desai, H. (1971). An Empirical Analysis of the Quality of Corporate Financial Disclosure The Accounting Review, 46(1), 129-138.

Spence, M. (1973). Job Market Signalling. Journal of Economics, 355-374.

Stanga, K. (1976). Isclosure in Published Annual Reports. Financial Management, $42-52$.

Street, D. L., \& Gray, S. J. (2002). Factors Influencing the Extent of Corporate Compliance with International Accounting Standards: Summary of a Research Monograph. Journal of International Accounting, Auditing and Taxation, 11, 51-76. http://dx.doi.org/10.1016/S1061-9518(02)00054-X

Street, D. L., \& Bryant, S. M. (2000). Disclosure level and compliance with IASs: A comparison of companies with and without U.S. listings and filings. The International Journal of Accounting, 35(3), 305. http://dx.doi.org/10.1016/S0020-7063(00)00060-1

Tower, G., Hancock, P., \& Taplin, R. H. (1999). A regional study of listed companies' compliance with international accounting standards. Accounting Forum, 23(3), 293-305. http://dx.doi.org/10.1111/1467-6303.00016

Verrecchia, R. E. (1983). Discretionary Disclosure. Journal of Accounting \& Economics, 5(3), 179. http://dx.doi.org/10.1016/0165-4101(90)90021-U

Wallace, R. S. O. (1987). Disclosure of Accounting Information in Developing Countries: A Case Study of Nigeria. Unpublished Ph.D Thesis, University of Exeter, U. K.

Wallace, R. S. O., \& Naser, K. (1995). Firm-Specific Determinants of the Comprehensiveness of Mandatory Disclosure in the Corporate Annual Reports of Firms Listed on the Stock Exchange of Hong Kong. Journal of Accounting and Public Policy, 14(4), 311-368. http://dx.doi.org/10.1016/0278-4254(95)00042-9

Wallace, R. S. O., Naser, K., \& Mora, A. (1994). The relationship between the comprehensiveness of corporate annual reports and firm characteristics in Spain. Accounting and Business Research, 25(97), 41. http://dx.doi.org/10.1080/00014788.1994.9729927

Watts, R., \& Zimmerman, J. (1983). Agency Problems, Auditing and the Theory of the Firm: Some Evidence. Journal of Law and Economics, 1226, 613-634.

\section{Appendix}

IFRS 8 disclosure checklist

\begin{tabular}{lll}
\hline No. Reference & Presentation/disclosure requirement & Score* \\
\hline & $\begin{array}{l}\text { This section of the checklist addresses IFRS 8, which requires certain entities to report } \\
\text { information regarding the nature and financial effects of their various operating } \\
\text { segments. }\end{array}$ \\
\hline No. Reference & Presentation/disclosure requirement \\
\hline
\end{tabular}


General information

An entity shall disclose the following general information:

$1 \quad$ IFRS 8:22(a)

a) factors used to identify the entity's reportable segments, including the basis of organisation; and

$2 \quad$ IFRS 8:22(b)

b) types of products and services from which each reportable segment derives its revenues.

Information about profit or loss, assets and liabilities

IFRS 8:23 For each reportable segment, an entity shall report a measure of: profit or loss

An entity shall report a measure of total assets and liabilities for each reportable segment .

An entity shall also disclose the following about each reportable segment if the specified

IFRS 8:23 amounts are included in the measure of segment profit or loss reviewed by the chief operating decision maker or are otherwise regularly provided to the chief operating decision maker, even if not included in that measure of segment profit or loss:

a) revenues from external customers;

b) revenues from transactions with other operating segments of the same entity;

c) interest revenue;

d) interest expense;

e) depreciation and amortisation;

f) material items of income and expense disclosed in accordance with paragraph 97 of IAS 1;

$11 \quad$ IFRS 8:23(g)

g) the entity's interest in the profit or loss of associates and joint ventures accounted for by the equity method;

h) income tax expense or income; and

i) material non-cash items other than depreciation and amortisation.

An entity shall report interest revenue separately from interest expense for each reportable segment unless a majority of the segment's revenues are from interest and the chief operating decision maker relies primarily on net interest revenue to assess the performance of the segment and make decisions about resources to be allocated to the segment.

Are a majority of the segment's revenues from interest and does the chief operating decision maker rely primarily on net interest revenue to assess the performance of the segment and make decisions about resources to be allocated to the segment? If yes :

The entity that reports that segment's interest revenue net of its interest expense shall disclose the fact that it has done so.

An entity shall disclose the following about each reportable segment if the specified amounts are included in the measure of segment assets reviewed by the chief operating decision maker or are otherwise regularly provided to the chief operating decision maker, even if not included in the measure of segment assets:

a) the amount of investment in associates and joint ventures accounted for by the equity method; and

b) the amounts of additions to non-current assets other than financial instruments, deferred tax assets, net defined benefit assets (see IAS 19 Employee Benefits) and rights arising under insurance contracts.

\section{Measurement}

19 IFRS 8:27

An entity shall provide an explanation of the measurements of segment profit or loss, segment assets and segment liabilities for each reportable segment.

At a minimum, an entity shall disclose the following:

20 IFRS 8:27(a)

a) the basis of accounting for any transactions between reportable segments;

b) the nature of any differences between the measurements of the reportable segments' profits or losses and the entity's profit or loss before income tax expense or income and discontinued operations (if not apparent from the reconciliations described in paragraph 28 of IFRS 8 -see below); 
IFRS 8:32

IFRS 8:33(a)

IFRS 8:28(e)

IFRS 8:29

IFRS 8:29

IFRS 8:33(a)

IFRS 8:33(b)

c) the nature of any differences between the measurements of the reportable segments' assets and the entity's assets (if not apparent from the reconciliations described in paragraph 28 of IFRS 8-see below);

d) the nature of any differences between the measurements of the reportable segments' liabilities and the entity's liabilities (if not apparent from the reconciliations described in paragraph 28 of IFRS 8-see below);

e) the nature of any changes from prior periods in the measurement methods used to IFRS 8:27(e) determine reported segment profit or loss and the effect, if any, of those changes on the measure of segment profit or loss; and

IFRS 8:27(f) $\quad$ f) the nature and effect of any asymmetrical allocations to reportable segments.

Reconciliations

An entity shall provide reconciliations of all of the following:

IFRS 8:28(a) a) the total of the reportable segments' revenues to the entity's revenue;

b) the total of the reportable segments' measures of profit or loss to the entity's profit or loss before tax expense (tax income) and discontinued operations;

IFRS 8:28(c) $\quad$ c) the total of the reportable segments' assets to the entity's assets;

d) the total of the reportable segments' liabilities to the entity's liabilities if segment liabilities are reported in accordance with paragraph 23 of IFRS 8 (see above); and e) the total of the reportable segments' amounts for every other material item of information disclosed to the corresponding amount for the entity.

IFRS 8:28 All material reconciling items shall be separately identified and described.

Restatement of previously reported information

Has the entity changed the structure of its internal organisation in a manner that causes the composition of its reportable segments to change?

If yes :

The corresponding information for earlier periods, including interim periods, shall be IFRS 8:29 restated unless the information is not available and the cost to develop it would be excessive.

An entity shall disclose whether it has restated the corresponding items of segment information for earlier periods.

If segment information for earlier periods, including interim periods, is not restated to reflect the change, the entity shall disclose in the year in which the change occurs segment information for the current period on both the old basis and the new basis of segmentation.

Entity-wide disclosures

Information about products and services

An entity shall report the revenues from external customers for each product and service or each group of similar products and services, unless the necessary information is not available and the cost to develop it would be excessive.

Where the disclosures required under paragraph 32 of IFRS 8 (see above) are not made because the information is not available and the cost to develop it would be excessive, that fact shall be disclosed.

Information about geographical areas

An entity shall report the following geographical information, unless the necessary information is not available and the cost to develop it would be excessive:

a) revenues from external customers:

i) attributed to the entity's country of domicile; and

ii) attributed to all foreign countries in total from which the entity derives revenues;

b) revenues from external customers attributed to an individual foreign country, where those revenues are material;

c) the basis for attributing revenues from external customers to individual countries;

d) non-current assets other than financial instruments, deferred tax assets, post-employment benefit assets, and rights arising under insurance contracts:

i) located in the entity's country of domicile; and

ii) located in all foreign countries in total in which the entity holds assets; and 

$44 \quad$ IFRS 8:33(b)
e) where non-current assets other than financial instruments, deferred tax assets,

$\begin{array}{ll}44 & \text { IFRS 8:33(b) } \\ 45 & \text { IFRS 8:33 } \\ 46 & \text { IFRS } 8: 33\end{array}$ post-employment benefit assets, and rights arising under insurance contracts in an individual foreign country are material, those assets are disclosed separately.
Where the necessary information for the disclosures required under paragraph 33 of IFRS 8 (see above) is not available, and the cost to develop it would be excessive, that fact shall be disclosed.
An entity may provide, in addition to the information required by paragraph 33 of IFRS 8 (see above), subtotals of geographical information about groups of countries. Information about major customers
$47 \quad$ IFRS 8:34 An entity shall provide information about the extent of its reliance on its major customers.
48 IFRS 8:34 Do revenues from transactions with a single external customer amount to 10 per cent or more of an entity's revenues?
If yes :
49 IFRS 8:34 The entity shall disclose that fact, the total amount of revenues from each such customer, and the identity of the segment or segments reporting the revenues.
Restatement of prior year segment information on adoption of IFRS 8
Segment information for prior years that is reported as comparative information for the
$50 \quad$ IFRS 8:36 initial year of application (including application of the amendment to paragraph 23 made in April 2009) shall be restated to conform to the requirements of IFRS 8, unless the necessary information is not available and the cost to develop it would be excessive.

\footnotetext{
Note. * Scoring Procedure:

$1=$ Requirement is complied with

$0=$ Requirement is not complied with

$\mathrm{N} / \mathrm{A}=$ Requirement is not applicable
}

\section{Copyrights}

Copyright for this article is retained by the author(s), with first publication rights granted to the journal.

This is an open-access article distributed under the terms and conditions of the Creative Commons Attribution license (http://creativecommons.org/licenses/by/3.0/). 